\title{
CAPITALISING ON POLISH TRANSLATION MARKET DATA IN THE FIELD OF COMMERCIAL LAW
}

\author{
Edyta WIĘCLAWSKA, PhD \\ Wydział Filologiczny \\ Instytut Filologii Angielskiej \\ Al. mjr. W. Kopisto 2B \\ 35-315 Rzeszów, Poland \\ edytawieclawska@poczta.fm
}

\begin{abstract}
The author presents data gathered in an online survey questionnaire (https://www.interankiety.pl/i/RGmj5rDv) which is a part of a broader research project related to the quality of translation of English language documents in the field of commercial law that are processed in the judicial registration proceedings in reference to the entities subject to registration at the Register of Entrepreneurs of the National Court Register (RP, KRS). The questions and hypotheses posed by the author relate to the relationship or comparison of nation-wide data concerning cases with foreign element in the context of the documents in translation on file in the National Court Register (source texts and their certified translations).

The survey is the first stage of this project and has been ascribed a number of aims: allowing for a definition of the genre profile of the corpus texts; identifying the general sociologically conditioned tendencies in their structure; and - primarily - determining the practically feasible search criterion
\end{abstract}


for compiling a design corpus for further quantitative and qualitative analysis of selected language structures (the ensuing stages of the said project).

Key words: interlingual communication; legal translation; commercial law; court settings

\title{
ZNACZENIE DANYCH RYNKOWYCH W TŁUMACZENIU TEKSTÓW PRAWA HANDLOWEGO
}

\begin{abstract}
Abstrakt: Autor prezentuje dane uzyskane w ramach przeprowadzonego badania sondażowego $\mathrm{z}$ wykorzystaniem ankiety autorskiej online (https://www.interankiety.pl/i/RGmj5rDv), które stanowi część większego projektu badawczego dotyczącego jakości pisemnych tłumaczeń dokumentów angielskojęzycznych $\mathrm{z}$ zakresu prawa handlowego, jakie stanowią załączniki w postępowaniu przed sądem rejestrowym, dotyczącym podmiotów podlegających wpisowi do Rejestru Przedsiębiorców Krajowego Rejestru Sądowego (RP, KRS). Postawione pytania badawcze lub hipotezy dotyczą relacji lub porównania ogólnopolskich danych dotyczących spraw $\mathrm{z}$ elementem zagranicznym w kontekście zalegających w aktach sądowych, w przedmiotowych wydziałach KRS dokumentów anglojęzycznych wraz $\mathrm{z}$ ich poświadczonymi tłumaczeniami.

Kwestionariusz został przeprowadzony z uwagi na wiele czynników: zdefiniowanie profilu gatunkowego tekstów, które bedą stanowić korpus, określenie ogólnych, socjologicznie uwarunkowanych tendncji w strukturze tych tekstów oraz - przede wszystkim - określenie wymiernego i możliwego do zastosowania klucza do wyłonienia kryterium wyszukiwania dokumentów, które będą stanowić korpus do przeprowadzenia dalszej analizy ilościowej oraz jakościowej wybranych struktur jezykowych (kolejne etapy projektu).
\end{abstract}

Słowa kluczowe: komunikacja interlingwalna, tłumaczenia prawnicze, prawo handlowe, kontekst środowiska sądowego.

\section{Introduction}

Legal translation is widely acknowledged to be a vast field in terms of practice and theory, where the linguistic structure of texts in translation is modelled by, among others, institutional factors, textual conditionings or the need for precision. Such complexity of the translation practice in the domain of law calls for the studies 


\section{Comparative Legilinguistics 33/2018}

covering this area of interlingual communication to account for the existing trends and/or guidelines with reference to the sociolinguistically-grounded factors. This involves consideration of market-related data, relevant discipline-related knowledge and - in reference to court translation, as is the case here conventions and practices adopted in the adjudication practice based on the processing of the translated texts. The main hypothesis adopted in this study rests on the idea that legal translation is a fuzzy category (Biel 2014:50) and it allows itself to be categorised in many ways depending on the criterion adopted, one of them being the criterion of thematic field which leads to the categorisation of legal translation according to branches in the legal system (Biel 2014:51). In the context of such a heterogenous character of legal translation, scholars acknowledge the variability of linguistic realisations in translating legal texts, depending on the textual and communicative context, and - as may be deduced - on the category of legal translation, in that they point to the need to adjust the target text tothe communicative needs and requirements of the target culture (e.g. Biel 2017: 316-336, Chromá 2014: 121-144, Flöter-Durr and Grass 2016: 87, Matulewska 2014: 167) ${ }^{1}$, whether these are imposed by institutional frameworks (Biel 2014) or emerge from an individually designed scenario. Further, it is argued that the genre factor is a significant determinant of the communication style adopted in translation (Albi 2013: 1-21, Goźdź-Roszkowski 2016: 51-67). Many studies advocate multi-perspective research in legal linguistics, which would also cover sociolinguistic aspects. Galdia (2017: 68-69) is an example here in that the scholar claims that legal linguistics involves research that is significantly heterogenous in terms of its interdisciplinary character with a strong pragmatic component.

In recognition of the distinctive character of specific categories of legal translation and the wide-ranging methodological framework of legilinguistics, it is hypothesised that translation of commercial law documents displays certain unique characteristics

${ }^{1}$ Such an assumption is also claimed in reference to other specialised languages (see, for example, Grabowski 2015: 23-33). 
which result from its sociocultural and sociolinguistic background. ${ }^{2}$ The study addresses the research problem of the sociolinguistic background of certified translations with regard to commercial law documents in the Anglo-Polish legal trade in court settings ${ }^{3}$ and the related scope of competence needed to practice translation in the said domain. ${ }^{4}$ Specifically, the research question posed by the author is whether there are any tendencies in the sociolinguistic profile of certified commercial law translations as processed in the adjudication process of the registration proceedings at the Register of Entrepreneurs of the National Court Register.

With the aim of fitting in with the ideological standpoint of such multi-perspective research and in order to formulate the answer for the research question posed, the author conducted an online survey questionnaire (https://www.interankiety.pl/i/RGmj5rDv). The survey is the first stage of a project devoted to the corpus analysis of court translations and it has been ascribed a number of aims: allowing for a preliminary definition of the genre profile of the texts making up the corpus-to-be; identifying the general sociologically-conditioned tendencies in their structure; and - primarily - determining the practically feasible search criterion for compiling a design corpus for further analysis (the ensuing stages of the said project). The survey covers nation-wide data. The respondents were judges and referendaries belonging to the judiciary in the Regional Courts, Economic Divisions, sections of the National Court Register (henceforth referred to as KRS, from the Polish Krajowy Rejestr Sadowy). ${ }^{5}$

${ }^{2}$ The term sociocultural is used here in reference to the notion of legal culture, where law - in the sense of institutions and values - constitutes an element of culture in general and legal culture is treated as an element of context (Jopek-Bosiacka 2010: 188-196). The term sociolinguistic is used in the wider sense as a concept embracing the totality of factors (also those exceeding the limits of the legal system) related to or having an influence on the linguistic structure of texts in translation or - in narrower sense in reference to the strictly sociolinguistic regime of texts in translation, without reference to the domain of law specifically.

3 The term court settings implies coming under the competence of the National Court Register.

${ }^{4}$ Certified translations are further referred to as translations or translated texts. For the sake of accuracy, it needs to be noted that the attribute certified is not consistently included in the questionnaire questions. The terms texts/documents in translation cover both source and target texts.

5 The acronym is used exclusively in the discussion. The graphical representations included in the paper follow their own conventions. 


\section{Methodology, Hypotheses}

The study consists in conducting a survey which took the form of a custom-designed questionnaire, henceforth referred to as the questionnaire. ${ }^{6}$ In terms of type of data, the study represents the desk research type. The questions did not address the subjective views of the respondents. The answers were to be based on facts, which was ensured by careful selection of the respondents. The structure of the questions was varied in order to meet the aim of the research; that is, in order to obtain information about the specific variables and it can be enumerated according to three categories. Hence, we have: (i) open questions (question no. 1 about the volume of cases in point) and halfopen questions, where the respondents are offered the option of submitting their own formula ('others, what kind of'); (ii) singlechoice questions (whenever a pie chart is provided) and multiple-choice questions; (iii) questions built against nominal scales and questions built against an ordinal scale. The questions making up the questionnaire are standardised and are based on the individual hypothetical assumptions of the author, derived from the main hypothesis, as discussed above, which sanctions the relevance of the linguistic and extralinguistic context for the translation practice, variability of forms and solution, as determined by the specific communicative background, the trends that were the target in the present study. Standardisation of the multiple and single choice options allows us to identify whether the data constitute specific patterns; in other words, whether the answers point to the analysed situation having a hermetic character.

The study is quantitative in nature (Wejland 1992: 51-81). It was conducted with the use of the CAWI technique (Computer Assisted Web Interviewing) and the data were analysed quantitatively and qualitatively (Babbie 2008: 421-476). The quantitative analysis was conducted with the use of the Statistical Package for the Social Sciences programme (Bedyńska and Brzezicka 2007: 181, Nawojczyk 2002: 223). The data gathered in the questionnaire has been quantitatively analysed in order to verify the nation-wide patterns in the volume and the distribution of the relevant language material with regards to such questions as the origin of the English texts on file, the dominant text genres, and the critical errors in translation.

The respondents constitute a homogenous group of adjudicators at the KRS, that is judges and/or court referendaries.

${ }^{6}$ For methodological details of the study see Schleef (2014: 42-57). 
The data presented herein were calculated as the average of the answers submitted by the respondents from 13 divisions of the KRS in Poland, one from each division. The population covers 28 units (court divisions of the said types in 21 cities). 13 units responded, which constitutes $46.4 \%$ of the total population. The data obtained come from various locations and thus they are representative of the nationwide tendencies. To ensure the reliability of the data the following conditions were met: (i) percentage of the answers is statistically significant, (ii) notification of the respondents and dissemination of the questionnaire is adequate, and (iii) respondents make up a homogenous group.

\section{Scope of Research with Reference to the Legal Background}

In order to facilitate the understanding of the context of the research let me briefly introduce the relevant institutional setting. The KRS is a court division and - at the same time - it is a centralised, computerised database of the entities that participate in the professional legal trade, in particular in the economic sphere. The KRS is an example of a public register that aims at maintaining records of specific organisational units operating in the civil law trade. Since it is centralised, it enables quick and easy access to the data from any KRS all over Poland (Ciulkin, Jakubecki and Kowal 2004: 36).

The KRS was created on the basis of the Act of $20^{\text {th }}$ August 1997 on the National Court Register (from Pol. Ustawa o Krajowym Rejestrze Sadowym) and has been in operation since $1^{\text {st }}$ January 2001. The KRS comprises three distinct registers: (i) the Register of Entrepreneurs (henceforth RP, from Pol. Rejestr Przedsiębiorców); (ii) the Register of Associations, other Social and Professional Organisations, Foundations and Public Healthcare Institutions; (iii) the Register of Insolvent Debtors. The object of the KRS is to provide reliable and up-to-date information related to the legal status of the entities in the register, their financial condition and manner of representation.

In the context of the aim of the study under discussion here the focus is on the RP whose functioning - by virtue of legislative 


\section{Comparative Legilinguistics 33/2018}

provisions $^{7}-$ involves trans-border and thus interlingual communication. Entities entered in the RP of the KRS include mostly commercial law companies, as enumerated in the Code of Commercial Companies (from Pol. Kodeks Spótek Handlowych), but the operation of these often involves a foreign factor.

In order to encapsulate the organising force for setting the research project on the right path, the author referred to the overriding notion of a case with foreign element which determined the conceptual framework of the questionnaire. The said concept was borrowed from the legal theory referred to as a case with foreign element defined as '[...] any court proceedings, where at least one party has a seat abroad, there is a need to examine evidence abroad or the object of the dispute is foreign' (Więclawska 2016: 245253 after Gołaczyński 2015). ${ }^{8}$ It was assumed that adjudication

7 As discussed in Więcławska (2013: 73-86) Polish legislation provides for the models of trans-border communication. The case in point is art. 89 of the Act on Freedom of Economic Activity (from Pol. Ustawa o Swobodzie Działalności Gospodarczej) which sets forth that filing of a branch of a commercial company with the registry court shall include specific documents and their certified translations:

'Niezależnie od obowiązków określonych w przepisach o Krajowym Rejestrze Sądowym przedsiębiorca zagraniczny jest obowiązany: [...]

3) jeżeli działa na podstawie aktu założycielskiego, umowy lub statutu złożyć ich odpisy do akt rejestrowych oddziału wraz z uwierzytelnionym tłumaczeniem na język polski';

[...] 4) jeżeli istnieje lub wykonuje działalność na podstawie wpisu do rejestru - złożyć do akt rejestrowych oddziału odpis z tego rejestru wraz $\mathrm{z}$ uwierzytelnionym thumaczeniem na język polski; [...]; Irrespective of the obligations defined in the statutory provisions on the National Court Register, a foreign entrepreneur is obliged: [...] 3) to file into register the copies of a founding act, articles of association of statutes, if he operates on the basis of these; sworn translation of the documents into Polish should be attached;

4) if he operates or carries out his business activity on the basis of the entry into the register - he is obliged to submit a copy of the certificate of incorporation into the register together with the sworn translation of this; [...] (translation mine).

8 'In a legal doctrine, the concept of a court case with a foreign element is most widely discussed in reference to the relevant EU regulations on jurisdiction, recognition and enforcement of judgements and the relevant domestic regulations in the EU Member States, that is Regulation (EU) No. 1215/2012 of the European Parliament and of the Council of 12 December 2012 on jurisdiction and the recognition and enforcement 
in such cases involves processing foreign documents in translation which the study refers. The questionnaire was constructed in such a way that the dominating trends in translation practice are identified with regards to the subject matter and the formal side of the registration proceedings together with their linguistic aspect from the perspective of adjudicators.

The notions of registration proceedings, the entry in the KRS, commercial law company, legal form, when considered in the light of legal trade with a foreign element were to constitute the sociocultural background for identifying the sociolinguistic profile of court translations in the said domain. On the operational side, functioning of the RP of the KRS is organised around registration proceedings which end with an entry in the RP of the KRS, unless motion for an entry is dismissed. Registration is not limited the first entry of a legal entity in the RP of the KRS (constitutive entry), but it also covers the entry of any change in the situation of a company (e.g. change of business name, change in representation). The registration proceedings take place in the form of an in-camera court session, where a judge or a referendary issues a decision about the entry or dismissal of an application for an entry in the sense outlined above. ${ }^{9}$ Importantly, the decision of the judge or referendary is made on the basis of a special form and appendices which may include documents in translation.

\section{Findings - Statistical Data}

The data included in the questionnaire may be said to relate to three main problem areas corresponding to the following research questions: (i) volume-related questions; (ii) questions related to the sociocultural context of the translation practice; and (iii) questions related to the issue of error in translation and its consequences on the adjudication practice. The discussion is organised according to the order of the problem areas mentioned above and it proceeds from the initial questions towards the final

of judgements in civil and commercial matters' (Więcławska 2016: 245253.)

9 The adjudication procedure also covers resorting to other instruments (e.g. orders in more specific cases); however, discussion of these would exceed the limits of this paper. 
sections of the questionnaire. The data are supported by relevant graphics presenting the distribution of all the answers that were submitted by the respondents. In the course of the discussion, at points the author resorts to some generalisations in presenting the values. The focus is on the tendencies that appear as negatively and positively extreme values and thus significant since they are illustrative of strong and statistically significant trends.

Three questions can be said to match the first category, referred to as volume-related data. The first of these included in Figure 1 rests on the hypothesis posed by the author in relation to the type of court proceedings run at the RP of the KRS, where the documents in translation serve as the foundation upon which the adjudication is based and - at the same time - respondents are asked about the relevant statistics. Here, the answer that was chosen most often was a value between 41 to 60 cases with a score of $30.8 \%$ of the total percentage of answers. The other four options, relating to the volumes of up to 10 , up to 20 , up to 40 and more than 60 , each account for $15.4 \%$ of the total percentage of answers. The least popular answer pointed to there being no data available.

Three of the respondents provided extra information to complete the standardised answer scheme. Namely, for two of the respondents their answers exceeded the standardised limits, in that choosing the option 'more than 60' they added a comment specifying that the total number of the said cases is to be placed in the range between 80 to 100 , and for the third respondent the answer was '200 cases'. Interestingly, one comment informed us that there are no systemic facilities to specify exactly the data that could be of interest to us. ${ }^{10}$ The following Figure 1 provides visual support for the data in question.

${ }^{10}$ The term systemic here is used with reference to the IT search mechanism in the electronic system of registration, as run by the RP of the KRS and it is not used in the sense it is commonly used in legilinguistic studies in relation to the intertextual character of legal discourse (e.g. Kjœr 2007: 506-515). 
Figure 1. Volume-related data: Cases with foreign element.

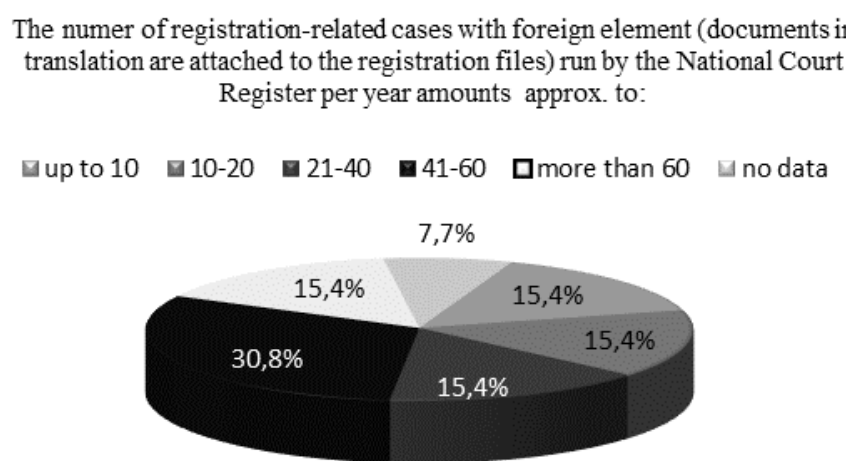

The next two pie charts relate to the volume of texts in translation that are of interest to us. Figure 2 allows us to place the English/Polish and Polish/English translations against the background of the total volume of texts in translation that serve as appendices in the court proceedings at the RP of the KRS. Here, the majority of the respondents claimed that the English/Polish or Polish/English translations constitute less than half of the total volume of texts in translation. Such answers were given by $46.2 \%$ of the respondents. $30.8 \%$ of the total volume of answers claimed that the texts in translation involving English and Polish language as a target or source language respectively constitute more than half of the total translation output attached to the court files under scrutiny. This choice, which is second in the total share of the output of answers, is followed by the answer "more or less than half of the total volume of all the texts in translation attached to the KRS files' with a score of $15.4 \%$. The statistically least significant answer, pointing to there being no documents in point, constitutes $7.7 \%$ of the total volume of answers. Figure 2 below evidences the data discussed above. 
Figure 2. Volume-related data: Distribution load of the Polish/English English/Polish translations in comparison to the total volume of certified translations.

\footnotetext{
Certified English « $($ Polish translations which are on files of the entities registered in the Register of Entrepreneurs of the National Court Register as compared to the number of certified translations from other languages $(0)$ Polish per year amount

$\square$ more than half of the total volume $\mathbf{M}$ approx. half of the total volume

less than half of the total volume there are no such documents
}

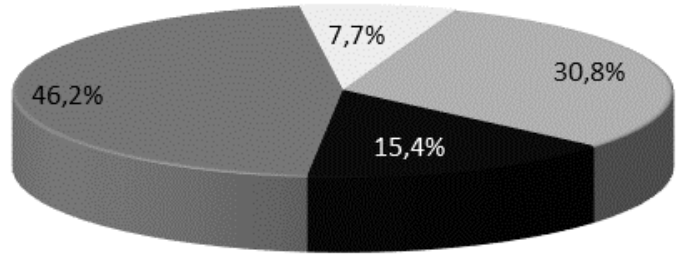

In an attempt to determine the relevant volume-related data in more detail the respondents were asked to provide answers in relation to the tendencies as regards the directionality of translation in the context of English and Polish interlingual communication in court settings. The tendencies seem to be clear here and the answers prove to be highly consistent. The vast majority of the respondents claimed that the documents in translation from English into Polish prevail (61.5\%). Only one respondent was of the opposite opinion, claiming that the distribution of the translation load leans the opposite direction, that is, translations from Polish into English being in the majority. Finally, answers indicating the exclusivity of translation from English into Polish and equality in the number of texts translated in both directions in point were in an absolute minority, each with a score of $15.4 \%$ of the total volume of answers. For visual illustration of the discussed trends, see Figure 3 below. 
Figure 3. Volume-related data: Directionality of translation in the AngloPolish translation market.

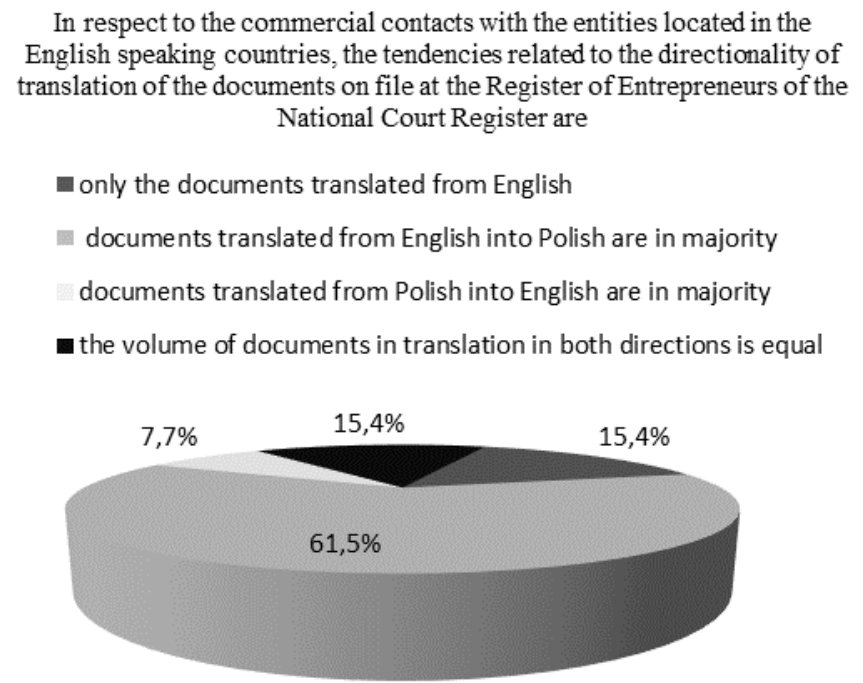

The data related to the problem area of sociocultural context were extracted from the answers to the multiple-choice questions in which the respondents were asked to specify the cultural background and - notably - culture here is to be understood as a concept embracing the legal system and rules prescribing the operation of the system (Jopek-Bosiacka 2010: 188-196). In short, the questions in point focus on the procedural aspect of processing the documents in translation ${ }^{11}$ in court settings in the said institutional context. The aim here was to collect information referring to: the relevant profile of court proceedings in which documents in translation are processed (Figure 4), the system-inherent possibilities of the extraction of these documents (Figure 5), their genres (Figure 6), the country of their origin (Figure 7) and - finally - the type of legal entity to which the documents in question relate, that is their legal form (Figure 8).

The information connected with the legal context is to enable the author to identify the areas in which the court practices involve processing documents in translation and - further - to account for the broader normative context. The respondents were asked in what type of cases the adjudication was based on the said

${ }^{11}$ From now on (conclusions excluded) the terms documents in translation, translations or translated texts refers exclusively to the Anglo-Polish translation market. 
documents. They were to choose one or more of the options related to registration of various entities. Specifically, two values scored around $70 \%$ of the total volume of answers and these point to the existence of documents in translation in cases related to the registration of a foreign branch of a company (69.2\%) and to the registration proceedings in relation to a company that has a shareholder who is a foreign entity $(76.9 \%)$. The third score that may be considered significant in terms of volume accounts for $38.5 \%$ and it provides for the registration proceedings in relation to the transborder merger of companies as a plausible context for the adjudication on the basis of documents in translation. For details that are relevant here, see the graphical representation provided below (Figure 4).

Figure 4. Sociocultural context: Type of registration proceedings, where documents in translation are processed.
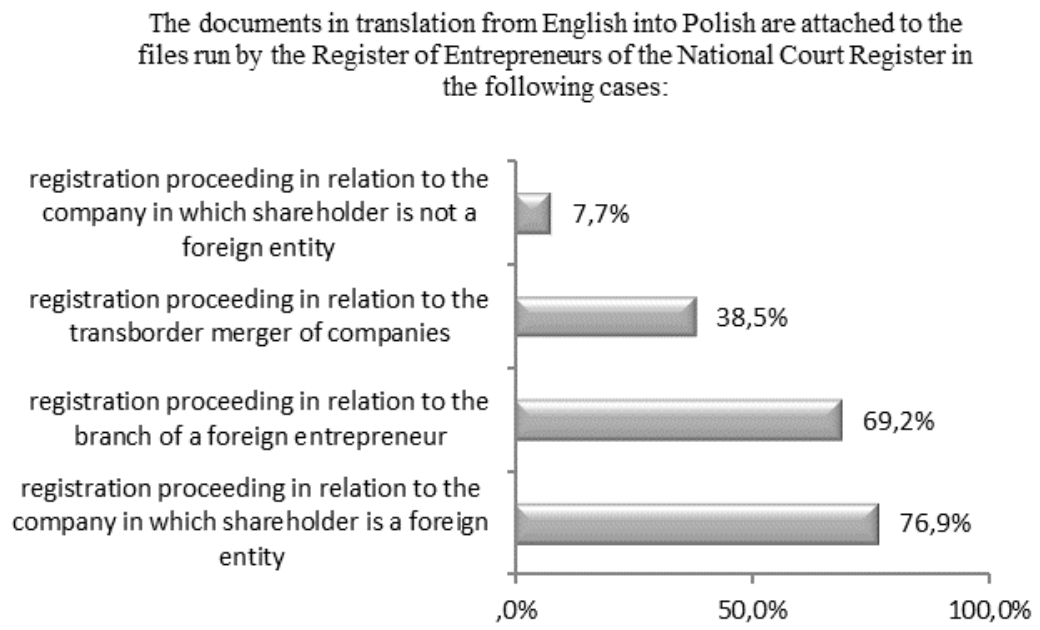

In order to determine the practical and system-related technical possibilities of localising the documents of interest for us on the court files in the institutional context covered by the analysis, the respondents were asked to answer the multiplechoice question related to the feasible search criterion. The respondents prove to be in considerable agreement here. Namely, more than $69 \%$ of the respondents opted to adopt the selection criterion based on the formula of the branch of a foreign company. The remaining answers scored slightly less than $40 \%$ each and as emerges from Figure 5 - these provide either for selecting cases, 
where one of the shareholders does not have either a REGON or PESEL number (38.5\% for each option individually). 30.8\% of the total population claim that there is no system-enhanced method that would enable us to select a statistically representative sample of texts in translation.

Figure 5. Sociocultural context: Search criteria for the compilation of the corpus. The search criterion for the selection of files including the documents in
translation into English may be as follows:

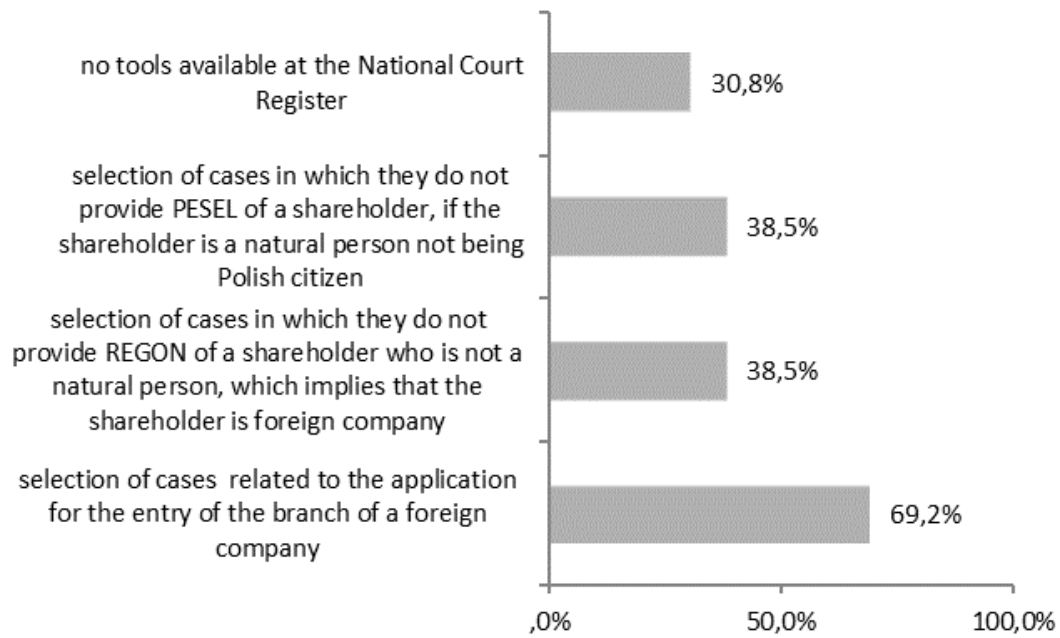

The data regarding the genre profile of texts in translation confirm the existence of specific trends. All the genres that the author hypothetically assumed to be processed in the specific court setting and proposed in the multiple-choice question as options to be selected were marked by the respondents but - as evidenced by Figure 6 - their frequency distribution proved to be unequal. The data in point can be considered in relation to three frequency distribution categories which can be naturally distinguished against the principle of approximated values. Hence, the 'written resolutions' and 'power of attorney' fit into a category comprising cases ascribed $100 \%$ occurrence. This is followed by the category of genre files, which scored $84.6 \%$ of frequency occurrence. This includes 'copy of registration certificate', 'copy of articles of association' and 'copy of statute'. The frequency distribution category that appears next 
in significance is not homogenous volume-wise. Here we have scores between $20 \%$ and $69.2 \%$ and the category is headed by documents labelled as 'current appointment report' and the lowest value in this category is ascribed to the document referred to as "notice of change of company name' with a value of $23.1 \%$. Finally, as evidenced in Figure 6 below, the fourth frequency distribution category comprises three items with a score of $7.7 \%$ and thus may be considered as statistically marginal. Two of the options that belong here - in most general terms - involve a specific type of application for the entry in the RP of the KRS and a statement about a change in company status, both in relation to a specific legal form, that is, limited partnership. The third choice considered to belong to the frequency distribution category in point here covers genres supplied by the respondents themselves as matching the open option 'others'. These are (i) 'contract for disposal of shares'; (ii) 'notarial certification of the authenticity of signatures'; (iii) 'apostille'. For a visual illustration of the discussed tendencies, see Figure 6. 
Figure 6. Sociocultural context: Genre distribution. ${ }^{12}$

Documents in translation into English that are on file of the entities entered in the Register of Entrepreneurs of the National Court Register are as follows:

(i) umowa zbycia udziałów/contract for disposal of shares; (ii) notarialne poświadczenie podpisów/notarial certification of the authenticity of signatures; (iii) /apostille

WNIOSEK O ZAREJESTROWANIE SPÓtKI KOMANDYTOWEJ/LPS APPLICATION FOR REGISTRATION OF LIMITED PARTNERSHIP OŚWIADCZENIE O ZMIANIE/LP6STATEMENT SPECIFYING THE NATURE OF CHANGE IN THE LIMITED PARTNERSHIP AND STATEMENT OF INCREASE IN THE AMOUNT CONTRIBUTED BY.. ZAWIADOMIENIE O ZMIANIE FIRMY SPÓtKI /NM01(EF) NOTICE OF CHANGE OF NAME BY RESOLUTION

MIANOWANIE DYREKTORA SPÓŁKI/AP02(EF) APPOINTMENT OF CORPORATE DIRECTOR

MIANOWANIE DYREKTORA/AP01(EF) APPOINTMENT OF DIRECTOR

AKTUALNY ODPIS Z REJESTRU/CURRENT APPOINTMENTS REPORT

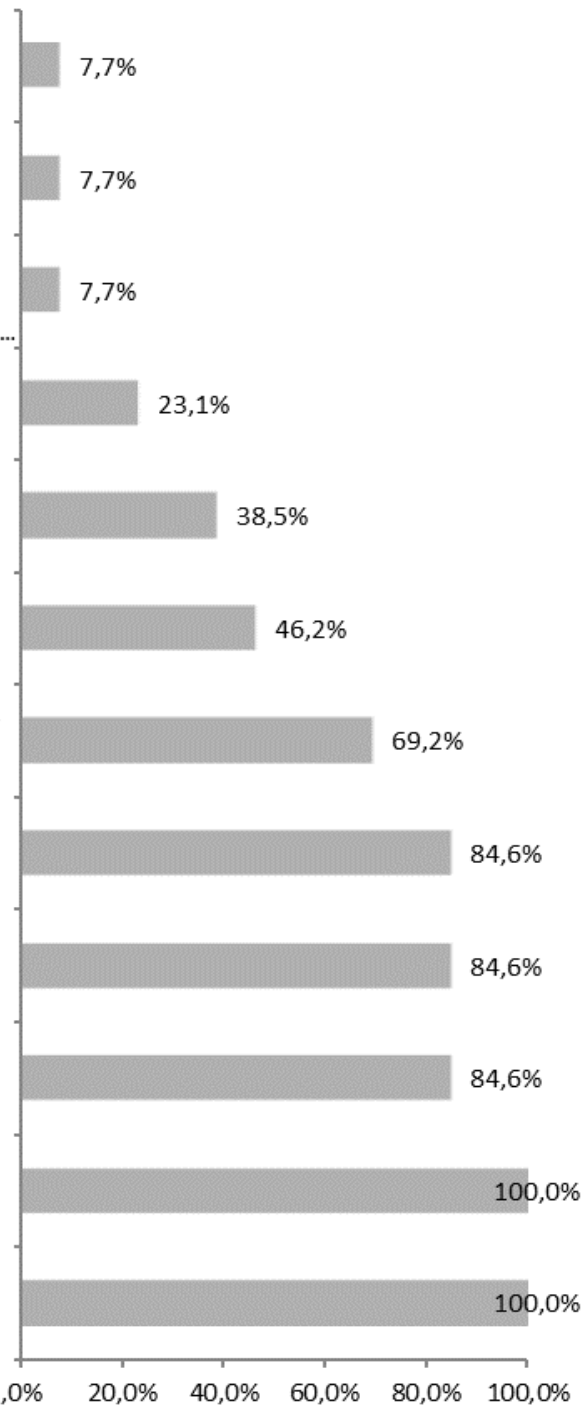

ODPIS Z REJESTRU/FILE COPY OF CERTIFICATE OF REGISTRATION

ODPIS AKTU ZAŁOŻYCIELSKIEGO/COPY OFARTICLES OF ASSOCIATION

ODPIS STATUTU/COPY OF STATUTE

UCHWAŁA/WRITTEN RESOLUTIONS

PEKNOMOCNICTWO/POWER OF ATTORNEY

$, 0 \% \quad 20,0 \% \quad 40,0 \% \quad 60,0 \% \quad 80,0 \% \quad 100,0 \%$

12 The titles of the documents are given in Polish and English since their translation is very much varied. 
The data on the source culture to which the documents in translation are affiliated point to the complexity of the issue of legal, interlingual communication within the field of commercial law trade. The point here is that English language documents as source texts in the said context appear to be filed in relation to entities administratively linked to companies primarily established outside the territory of English-speaking countries and functioning on the territory of the Republic of Poland, or in the case of a shareholder who is a foreigner but not necessarily a citizen of an English-speaking country. The English language, as lingua franca, is not reserved as a language of communication the countries, where it has the status of official language. Notably, using English as a communication language in the said context is made possible in view of the lack of normative conditionings that would impose the obligation of having all the documents filed at the RP of the KRS to be certified translations ${ }^{13}$.

Hence, we see in Figure 7 that - although marginally in one case (7.7\%) - English is present in the interlingual communication in the context of commercial law trade between entities whose operation involves, for example, an entity outside any English-speaking country. This may be the case of a company established in Germany or one that has a shareholder who is a German citizen.

In general, Figure 7 shows that, apart from the fairly obvious high position of Great Britain, the United States and Ireland here, Cyprus holds the second top-most position with a score of $38.5 \%$. This confirms the high position of the English language in interlingual communication settings in post-colonial countries.

${ }^{13}$ The legislator strictly prescribes the form of certified translations, which implies translation from the official language of a given country only for specified documents. For further information see the comment in footnote 7. 
Figure 7. Sociocultural context: State affiliation of the English document at KRS

What is the origin of the documents in translation into Polish which are on registration files?

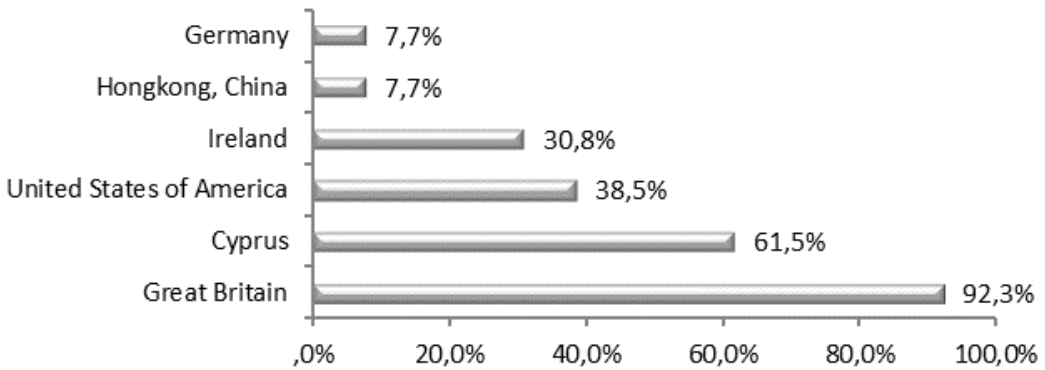

Establishing the existing trends with regards to the frequency of occurrence of specific legal forms is important in terms of delineating the extralinguistic context for translation practice in court settings. Most imminently, it enables us to closely identify the sociocultural dimension of the translation trade and thus bearing in mind the interdisciplinary character of legal translation practice and education - profile the thematic competence derived from the relevant normative regulations applicable for the specific legal forms included in the frequency list and - in particular - those that score the highest results on the list (see Figure 8).

Referring to the frequency data on the legal forms presented in Figure 8 below, the champion here is the legal form denoted as Limited, alternatively occurring in the short form $L t d$. with a score of $100 \%$. In general, the respondents selected all the options proposed by the author in the standardised multiple-choice scheme, though the frequency distribution differs, as testified by the data emerging from Figure 8. Corp. and LLP occupy the second top-most position with $46.2 \%$ each and are followed by $L P$ scoring $15.4 \%$. The last place belongs to the legal forms referred to as $L p$., $S E$ and partnership, the latter being the option provided by the respondents themselves in the space 'others, specify what kind of'. 
Figure 8. Sociocultural context: Legal forms of the entities managing interlingual communication.

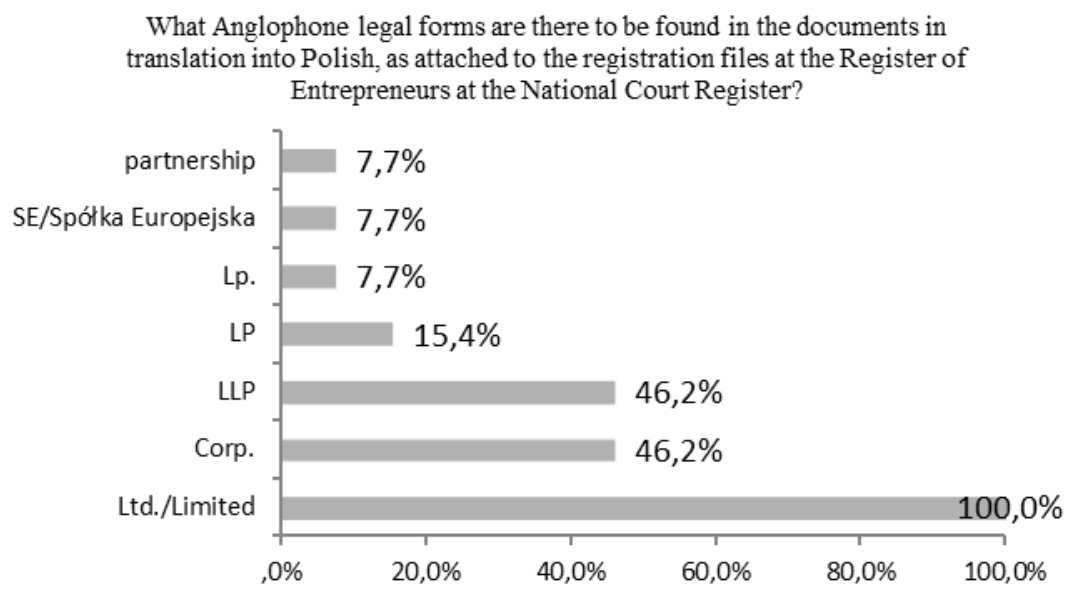

The problem area of translation quality is the third and final conceptual category where the remaining data emerging from the questionnaire can be subsumed. The data that introduce us to the linguistic context of the study in general relate to the adjudication procedure in the outlined context, the concept of critical error, factors leading to linguistic unnaturalness and finally ways of increasing the communicative value of the translation.

The question included in Figure 9 raises an issue of high importance in that it puts the texts in translation into their functional context as texts that are aimed at the exercising of a specific function in the registration proceedings leading to the award of an entry. Namely, the respondents are asked whether the subject matter of formal inaccuracy in a translation can result in the dismissal of the application for an entry to the RP of the KRS.

In general, the respondents were rather negative about the possibility of an entry into the RP of the KRS being refused for translation-inherent reasons (69.2\%). To specify the finding further, $15.4 \%$ of the respondents claimed that the said scenario is not possible. $53.8 \%$ of the respondents shared the same opinion, with the reservation of not being absolutely certain about the answer. Possibly here, the lack of complete, systemic data extracted by the application of a specific information technology solution was a factor. There is one answer, accounting for $7.7 \%$ that points somewhat hesitatingly to the possibility of a negative outcome of 
court proceedings caused by factors related to the text in translation. $23.1 \%$ of the respondents did not opt for either a positive or a negative answer, instead choosing the answer 'I do not know'. Figure 9 visualises the distribution of the values in point.

Figure 9: Linguistic context: Dismissal of an application for entry to the KRS.

\section{Does it happen that an application for the entry to the Register of Entrepreneurs of the National Court Register is dismissed due to subject matter mistake or formal inaccuracy in the certified translation of a document on file?}

घrather 'YES' $\square \mathrm{I}$ do not know $\square$ rather 'NO' $\square$ abosolutely 'NO'

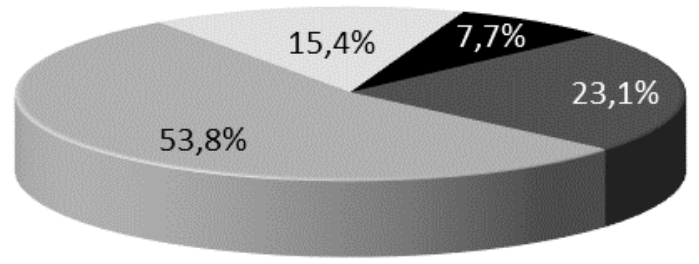

Figure 10 is illustrative of the data linked to the specificities of language structure in translation which significantly negate the validity of the translation in terms of the partywise positive outcome of the registration proceedings. The question here relates to the specific category of intralinguistic errors ${ }^{14}$, namely errors of usage, also referred to as stylistic errors. Systemic errors (language errors covering grammar, lexis and phonetics) were excluded from the study since the author did not aim at investigating language incompetence in the general sense, but focused on the register-related failures in translation. ${ }^{15}$ The data related to the representation

${ }^{14}$ Errors can be divided into extralinguistic (from Pol. zewnatrzjęzykowe) and intralinguistic (from Pol. wewnatrzjęzykowe). The latter are divided into two categories with further subcategories: (i) systemic errors, also referred to as linguistic errors: grammatical, lexical and phonetic errors and (ii) errors of usage, also referred to as stylistic errors. For a complete categorisation of errors see (Kubacki 2012:218 after Markowski 2002).

15 Kubacki (2012:218) defines errors of usage as 'niewłaściwy dobór środków językowych polegający na niedostosowaniu ich do charakteru i funkcji wypowiedzi' [.... Niewłaściwy rejestr, styl, nadawanie wyrazom nowych znaczeń'. '[...] improper choice of linguistic means which consists in failure to match them to the character and the function of the utterance. 
of a given entity applying for registration at the RP of the KRS constitute a critical area in that a majority of the respondents (69.2\%) find it the most important element of language structure, where inaccuracy is to be particularly avoided. Not much more than $30 \%$ of the respondents chose the answer related to the legal form. The remaining answers reached values below $16 \%$. They were appellative forms with a value of $15.4 \%$ and an answer with a value of $7.7 \%$ that excludes all of the standardised options provided in the multiple-choice set.

Figure 10. Sociolinguistic context: Critical error area.

Which elements of the language structure in the certified translations are critical mistakes - the inaccuracy of the translation can result in the refusal of the entry?

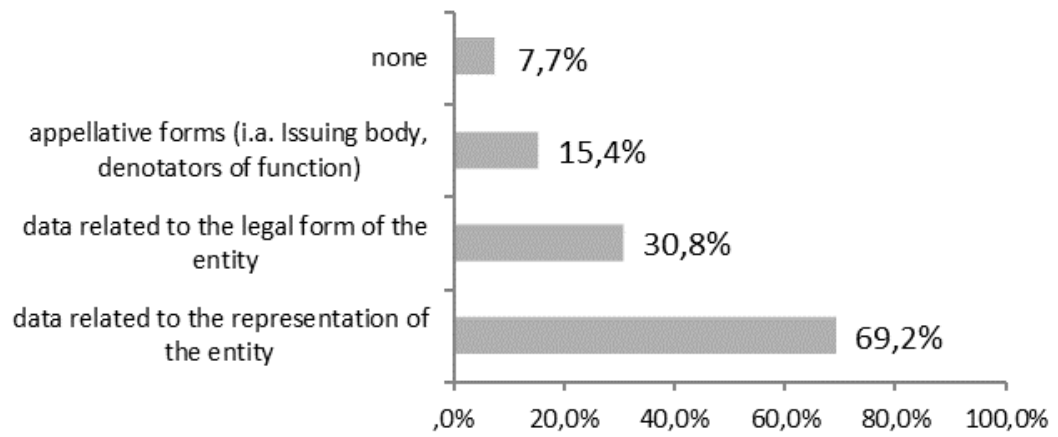

.Another set of data related to the problem area in the sociolinguistic context is provided by the respondents answering the question about the reasons for unnaturalness of the translation-based communication. Inadequate terminology heads the list, accounting for $76.9 \%$ of the total volume of answers. The second place is occupied ex equo by a literal character of translation and employment of forms outside the legal register, with a score of 53.8\% each. Inconsistency in translation with regard to terminology and text structure seems to be much less significant for legal practitioners $(23.1 \%)$. One respondent went even further by saying that form is not important.

[...] Improper register, style and use of terms with distorted meaning.'; translation mine. 
Figure 11. Sociolinguistic context: Problem areas in the language of translation.

The reason for which the certified translations into English on file at the Register of Entrepreneurs of the National Court Register are often unclear and languagewise unnatural:

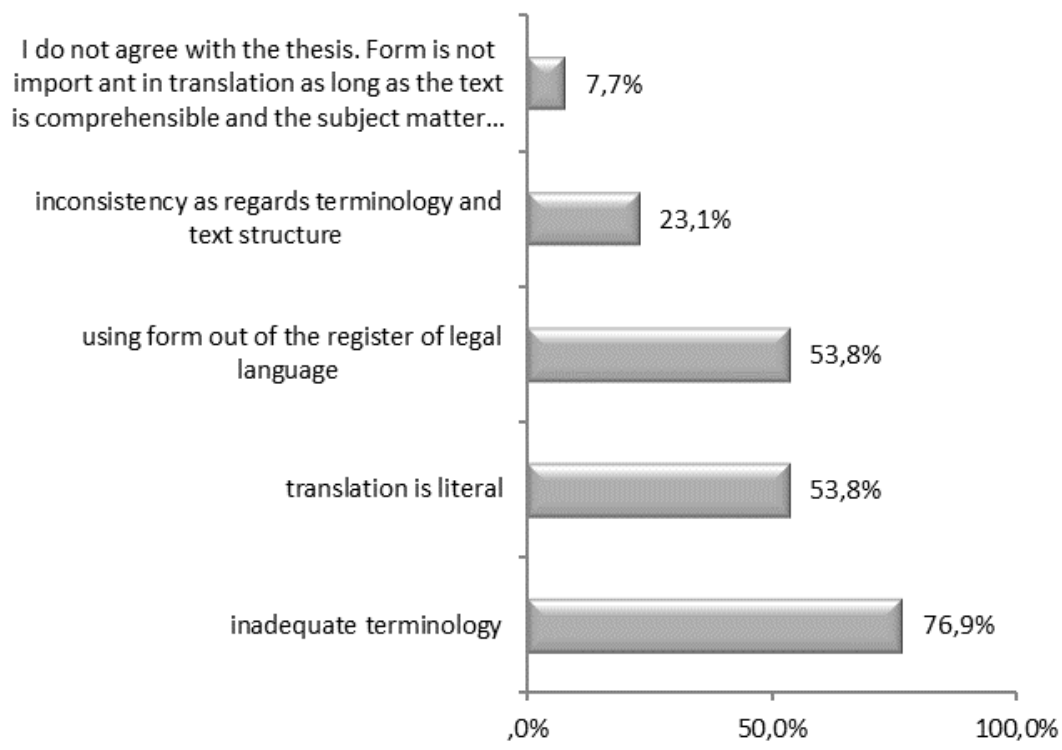

The last question referred to identification of the factors that could increase the communicative strength of texts in translation. This was in the form of a multiple-choice question and the respondents were asked to choose from 5 values of variables. The most frequent choices include provision of an explanatory footnote in a case where a translator encounters an untranslatable term. Such may be the case with culture-bound terms.

This value was followed by taking into account normative prescriptions of the target legal culture (79.9\%). More than half of the population $(53.8 \%)$ opted for preserving original terms in the target text. The two bottom-most values of variables $(15.4 \%)$ involve sticking to the target-language or source-language stylistic conventions. 
Figure 12. Sociolinguistic context: Factors increasing the communicative value of translations.

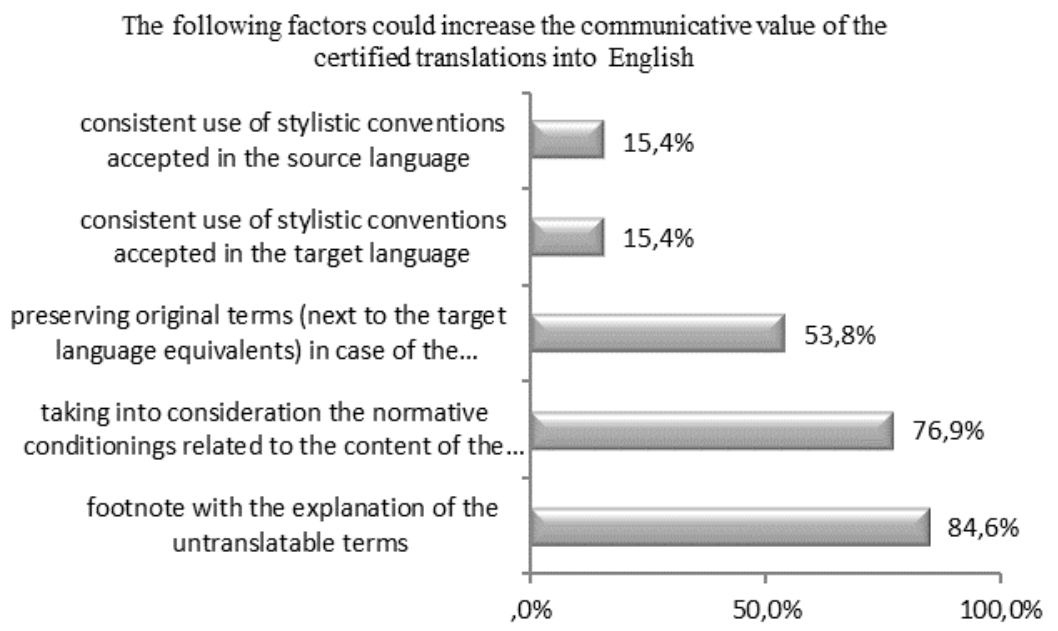

\section{Conclusions}

The study was an attempt at identifying a general sociolinguistic context for the certified translation market of commercial law documentation in court settings, with special focus on Anglo-Polish translation. The data obtained in the questionnaire were analysed with the use of quantitative methods, which allowed us - in the most general terms - to formulate some findings with respect to the frequency of specific phenomena and the distribution of textual features in the domain under scrutiny. The data can be said to be related to three main problem areas: volume-related context, sociocultural context and sociolinguistic context, in the senses ascribed to them in this paper. In general, the study aimed to provide answers to the following research questions:

1. How big is the commercial translation market in court settings and what part of it is occupied by Anglo-Polish translations?

2. What is the legal background with respect to the case category, type of registration proceedings, category of legal entities and type of documents that are relevant for the translation process? 
3. Are the documents in translation accurate in terms of linguistic structure, if not - where do they fail?

To sum up, the results show a considerably hermetic sociolinguistic profile of the translation market in the scope examined, in that the majority of the respondents selected the standardised answer options and rarely added their individually formulated responses. This shows that the hypotheses upon which the questionnaire was built were justified. Further generalisation of the results leads to the formulation of conclusions on two levels. On the one hand, the findings confirmed the existence of definite and strong tendencies in some areas with respect to the frequency and distribution of events and/or features, which shows that some phenomena are present and widely common irrespective of the territorial competence of the court where a given judge or referendary adjudicates and - consequently - irrespective of the amount of the workload at a specific KRS or the individual professional experience of the adjudicator themselves. This includes, for example, the two top-most results for the most common genre categories, with scores of $100 \%$. On the other hand, without prejudice to the conclusion presented above, in some respects the distribution of values was more dispersed, in that the percentages for various answers were fairly equal. The data related to the case category involving the processing of documents in translation are illustrative here. It may be assumed that there is a correlation between the amount of case turnover at specific courts, which is determined by geographically-conditioned economic factors, and the scope of pattern diffusion with respect to the sociolinguistic profile.

The conclusions would not be complete without making reference to the research limitations encountered by the author. The data, although statistically significant in view of the size of the population, provide very general information addressing the research problem and they should and will be further quantitatively and qualitatively analysed in the ensuing stages of a larger project involving corpus analysis. This is true especially in view of the fact noted by one of the respondents that there exist no technical facilities that would enable us to filter the specific data from the computerised system run by the RP of the KRS. The data presented here are desktop data provided on the basis of on-hand experience. 
The scope of the research in the broad sense may be perceived as a factor pointing to the originality of the study and - in terms of the subject matter - its significant practical implications. Firstly, the data have nation-wide scope and thus they constitute an original and important part of the research into the field of the translation market. Secondly, the originality of the study lies in its interdisciplinary character, in the fact that the judiciary is addressed, and more importantly in presenting the insider perspective of the authorities involved in functionally-oriented evaluation of the documents in translation. This is crucial given the fact that an application for registration may be dismissed or accepted depending on the specific linguistic forms used.

On the practical side, the data obtained in the questionnaire: (1) provide guidelines for further project work related to the compilation of the custom-designed corpus (what to look for, possible volume to be obtained, search methodology) and (2) serve as a factor in the selection of the specific population (courts and cities where a search of court files will be conducted) to ensure the representative character of the corpus.

\section{References}

Albi, Anabel Borja. 2013. A genre analysis approach to the study of the translation of court documents. Linguistica Antverpiensia 12: 33-53.

Babbie, Earl. 2008. Podstawy Badań Społecznych. Warszawa: PWN. Bedyńska, Sylwia and Aneta Brzezicka. 2007. Statystyczny drogowskaz. Warszawa: Wydawnictwo Szkoły Wyższej Psychologii Społecznej 'Academika'.

Biel, Łucja. 2014. Lost in the Eurofog: the Textual Fit of Translated Law. Bern: Peter Lang.

Biel, Łucja. 2017. Enhancing the communicative dimension of legal translation: comparable corpora in the research informed classroom. The Interpreter and Translator Trainer 11: 316336.

Chromá, Marta. 2014. Making sense in legal translation. Semiotica 201: 201-144. 
Edyta WIECCAAWSA: Capitalising on Polish Translation...

Ciulkin, Leszek, Andrzej Jakubecki and Norbert Kowal. 2004. Krajowy Rejestr Sadowy $i$ Postepowanie Rejestrowe. Praktyczny Komentarz. Warszawa: Wydawnictwo ZPP.

Flöter-Durr, Margarete and Thierry Grass 2016. Kommunikative Probleme in der Rechtsübersetzung. Quo Vadis Romania. 80 QVR 48: 80-93.

Galdia, Marcus. 2017. Lectures on Legal Linguistics. Frankfurt am Main: Peter Lang.

Gołaczyński, Jacek (ed.). 2015. Jurysdykcja, uznawanie orzeczeń sadowych oraz ich wykonywanie $w$ sprawach cywilnych $i$ handlowych. Rozporzadzenie Parlamentu Europejskiego $i$ Rady (UE) $n r$ 1215/2012. Komentarz. Warszawa C.H.Beck.

Goźdź-Roszkowski, Stanisław. 2016. The role of generic competence and professional expertise in legal translation. The case of English and Polish probate documents. Studies in Logic, Grammar and Rhetoric 45(58): 51-67.

Grabowski, Łukasz. 2015. Keywords and lexical bundles within English pharmaceutical discourse: a corpus-driven description. English for Specific Purposes 38: 23-33.

Jopek-Bosiacka, Anna. 2010. Legal Communication: Cross Cultural Perspective. Warszawa: Warsaw University Press.

Kjœr, Lise Anne. 2007. Phrasemes in legal Texas. In Phraseologie. Ein Internationales Handbuch der Zeitgenössischen Forschung/Phraseology. An International Handbook of Contemporary Research, ed. Harald Burger, Dmitrij Dobrovol'skij, Peter Kühn and Neal. R. Norrick, 506-515. Berlin/New York: Walter de Gruyter.

Kubacki Artur, Dariusz. 2012. Ttumaczenia Poświadczone. Status, Ksztatcenie, Warsztat Odpowiedzialność Ttumacza Przysięgłego. Warszawa: Wolters Kluwer.

Markowski, Andrzej. 2002. (ed.). Nowy Stownik Poprawnej Polszczyzny. Warszawa: PWN.

Matulewska, Aleksandra. 2014. In quest for attaining sufficient equivalence. Polish and English insolvency terminology in translation. A comparative study. Studies in Logic, Grammar and Rhetoric. vol. 38 (51): 167-188.

Nawojczyk, Maria. 2002. Przewodnik po Statystyce dla Socjologów. Kraków: SPSS Polska Sp. z o.o.

Schleef, Erik. 2014. Written Surveys and Questionnaires in Sociolinguistics. In Research Methods in Sociolinguistics. 
A Practical Guide. ed. Janet Holmes and Kirk Hazen Wiley, 42-57. Oxford: Wiley Blackwell.

Wejland, Andrzej P. 1992. Kwestionariusz. In Podręcznik Socjologicznych Badań Ankietowych. ed. Paweł Daniłowicz, Zbignew Sawiński, Franciszek Sztabiński, Paweł B. Sztabiński, Andrzej P. Wejland, 51-81. Warszawa: Instytut Filozofii i Socjologii PAN.

Więcławska, Edyta. 2013. On various degrees of stability of multiword combinations in the language of Polish law. International English Studies Journal, Studia Anglica Resoviensia. 10: 73-86.

Więcławska, Edyta. 2016. Integrating the needs of the local market in teaching legal translation. Humanities and Social Sciences. 23(2/2016): 245-253.

\section{Legislative Texts}

Ustawa z dnia 2 lipca 2004 r. o Swobodzie Działalności Gospodarczej (Journal of Laws of 2004, no. 174, item 1807 with later amendments).

Ustawa z dnia 20 sierpnia 1997 r. - Przepisy wprowadzajace ustawe o Krajowym Rejestrze Sadowym (Journal of Laws of 1997, no. 121, item 770 with later amendments)

Ustawa z dnia 15 września 2000 r. Kodeks Spółek Handlowych. (Journal of Laws of 2000, no. 94, item 1037 with later amendments). 